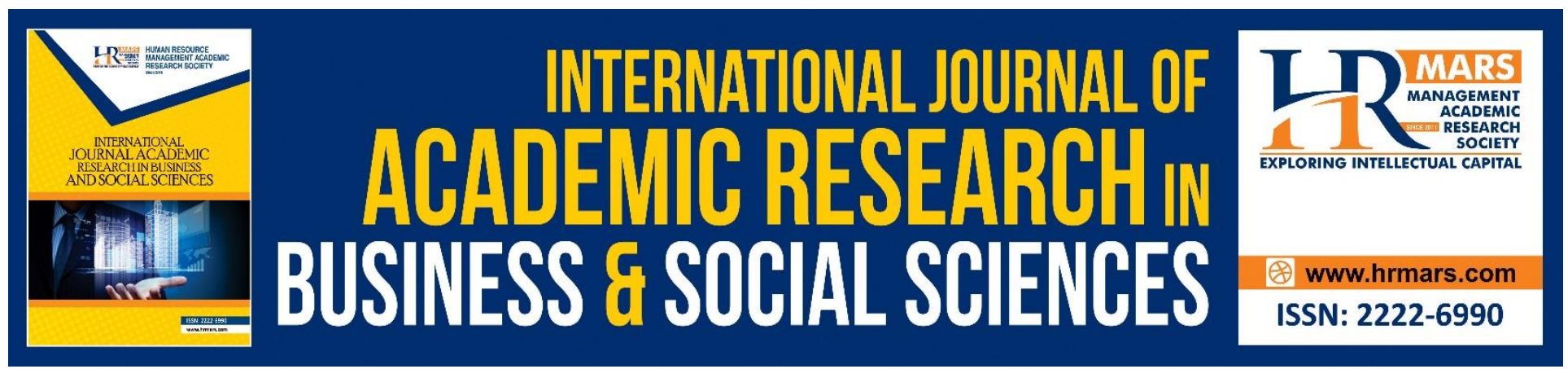

\title{
Zakat on Gold and the Awareness of Muslims in Terengganu
}

\author{
Engku Muhammad Tajuddin Engku Ali, Ahmad Tirmizi Taha, Mahadi \\ Mohammed, Syed Mohd Azmi Syed Ab Rahman \& Zaharah Salwati Baba
}

To Link this Article: http://dx.doi.org/10.6007/IJARBSS/v8-i10/4751

DOI: $10.6007 /$ IJARBSS/v8-i10/4751

Received: 07 Sept 2018, Revised: 18 Oct 2018, Accepted: 23 Oct 2018

Published Online: 31 October 2018

In-Text Citation: (Ali, , Ahmad Tirmizi Taha, Rahman, \& Baba, 2018)

To Cite this Article: Ali, E. M. T. E., , Ahmad Tirmizi Taha, M. M., Rahman, S. M. A. S. A., \& Baba, Z. S. (2018). Zakat on Gold and the Awareness of Muslims in Terengganu. International Journal of Academic Research in Business and Social Sciences, 8(10), 500-508.

\section{Copyright: (C) 2018 The Author(s)}

Published by Human Resource Management Academic Research Society (www.hrmars.com)

This article is published under the Creative Commons Attribution (CC BY 4.0) license. Anyone may reproduce, distribute, translate and create derivative works of this article (for both commercial and non-commercial purposes), subject to full attribution to the original publication and authors. The full terms of this license may be seen

at: http://creativecommons.org/licences/by/4.0/legalcode

Vol. 8, No. 10, 2018, Pg. 500 - 508

http://hrmars.com/index.php/pages/detail/IJARBSS

JOURNAL HOMEPAGE

Full Terms \& Conditions of access and use can be found at http://hrmars.com/index.php/pages/detail/publication-ethics 


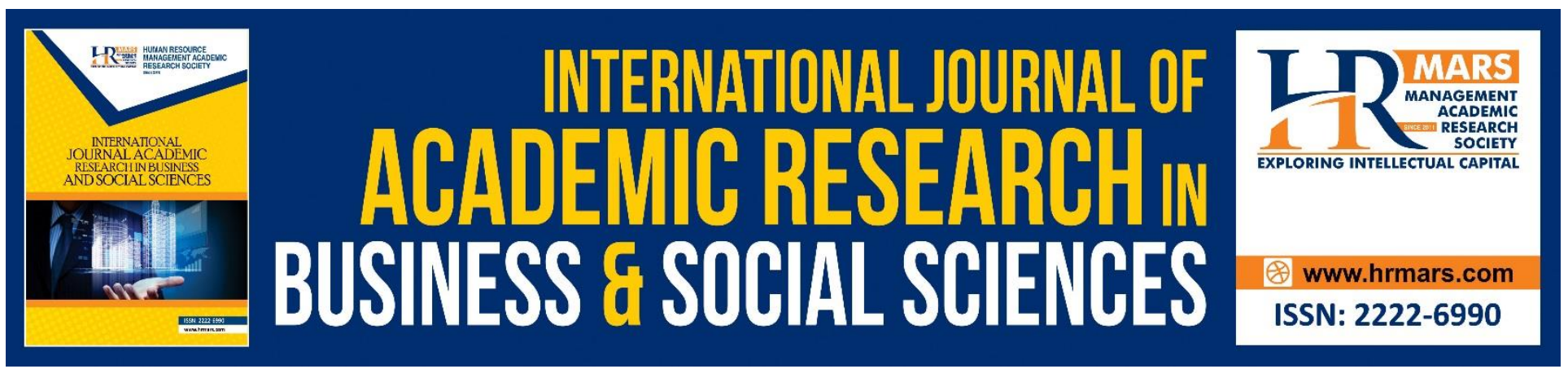

\title{
Zakat on Gold and the Awareness of Muslims in Terengganu
}

\author{
Engku Muhammad Tajuddin Engku Ali, Ahmad Tirmizi Taha, \\ Mahadi Mohammed, Syed Mohd Azmi Syed Ab Rahman, \& Zaharah \\ Salwati Baba
}

Faculty of Islamic Contemporary Studies University of Sultan Zainal Abidin, Malaysia.

\begin{abstract}
Islam has laid down clear rules and regulations related to wealth on which zakah is a religious obligation. Zakah is made obligatory among others on life stock, agricultural product, gold and silver, business profits and treasure. Although gold is clearly mentioned as items subjected to zakah, the knowledge of Muslims about its details is still questionable. This study aims to identify the level of knowledge among Muslims in Terengganu on the rules and regulations of zakah on gold. This study will use a quantitative approach with the aim of revealing the measure of knowledge among the Muslim society in Terengganu on zakat related to gold. This outcome will help the relevant religious authorities in Terengganu to undertake appropriate measures in order to increase the level of knowledge among the society on this pillar of Islam component.
\end{abstract}

Keywords: Gold, Zakah, Jewelleries.

\section{INTRODUCTION}

Zakah is among obligations that represent an act of worship performed by every competent Muslims. It is one of the five pillars of Islam. Zakah is also the core element for the socio-economic system in Islam. A good administration of zakah can stabilise the Muslims' economy. The positive impact of zakah had been proven in the days of the Caliph Umar bin Abdul Aziz, where there was no pauper or poor who is entitled to receive zakah distribution because everybody managed to get themselves out of the poverty circle. The role of zakah in stabilising the economy must be seen from a holistic perspective, and not only limited to the collection and distribution of zakah in a conventional context. 
Zakah has been mentioned 28 times in the Holy Quran together with solah (prayer). This gives us a general understanding that both acts of worship are interrelated. Allah says among others in surah A-Taubah verse 103: "Take, [O, Muhammad], from their wealth a charity by which you purify them and cause them increase, and invoke [Allah's blessings] upon them. Indeed, your invocations are reassurance for them. And Allah is Hearing and Knowing". In another verse, Allah says: "And from their properties was [given] the right of the [needy] petitioner and the deprived" (surah al-Dzariyat: 19).

Zakah is not subjected on every type of wealth. Only certain types of wealth are subjected to zakah. These types of wealth has been mentioned by Allah in the Holy Quran; they are gold and silver, agricultural produces, live stocks, business profit, minerals and treasure. (al-Zuhayli, 1989). These types of wealth are mentioned as a general context in the Holy Quran. Apart from these types of wealth, there are additional types of wealth that are also subjected to zakah. A more detailed description on these types of wealth can be found in the tradition of the Prophet SAW whether by his conduct or his order (al-Qaradawi, 1986).

The absurdity of human being towards gold is not a new thing. Gold has been adored by man notwithstanding their religion or race from time to time. This is not surprising because the love of human towards gold is something nature. Allah has created this love in humans' heart as a mean of test. Does human willing to sacrifice their wealth including gold in order to seek the forgiveness of Allah? (Ali, Mohammad \& Taha, 2015). Among these test is through the obligation_of zakah on gold.

In addition to the types of wealth as mentioned, there are other kinds of wealth on which zakah should be paid and its required percentages are left to the Sunnah to illustrate, by examples or directives (al-Qaradawi, 1986). It is the Sunnah that provides the details of the general Quranic commands and to convert the theoretical axioms of the Quran into a living reality in human life.

The Muslims jurists are unanimous that gold and silver are subjected to zakah (Ibn Rusd, n.d.). Allah says in surah al-Tawbah, verse 34 to the meaning: "...And there are those who hoard gold and silver and spend it not in the Way of Allah; announce unto them a most grievous chastisement". The nisab (lowest amount) for gold is twenty dinar which is equivalent to 96 gram. The nisab for silver is two hundred dirham which commensurate to 672 gram. The rate of zakah that will be taken from both gold and silver which have reached the said nisab is $2.5 \%$. The Prophet said: "Nothing is imposed on less than twenty dinar of gold, and for twenty dinar you have to pay half a dinar (2.5\%)" (al-Bayjuri, 1994). Jewelleries made of gold and silver that are kept and not used are also subjected to zakah. On the other hand, jewelleries that are legally used such as gold rings being worn by women or silver rings worn by men are exempted from zakah. However, jewelleries that are extravagant, even when

used by women are still subjected to zakah. Extravagance jewelleries are defined as anything above the customary use by women within a particular community. It also means to exceed the limits. (alSharbini, 1978).

\section{RESEARCH METODOLOGY}

This is a quantitative study. Primer data will be sought through survey technique in order to measure the level of knowledge among Muslims in Terengganu on the rules and regulations related to zakah on gold. Using the questionnaire as an instrument, a set of questions containing identified items will be distributed to selected sample. The respondents' knowledge on the rules and regulations related 
to zakah on gold will be measured using Likert scale with ten options of answers to be chosen from. In order to test the validity and trustworthiness of the questionnaire used, a pilot study involving forty respondents from Kuala Terengganu was also conducted. This pilot study also aims to ensure that the questionnaire are apprehensible_and at the same time to identify possible limitations during the actual data collection process. The verified questionnaires were distributed among three hundred and fifty Muslim respondents all over the state of Terengganu who are selected through the purposive sampling technique. Data management and analysis is performed using the SPSS version 13 software.

\section{RULES AND REGULATIONS ON ZAKAH ON GOLD}

The Islamic laws corresponding to gold also include rules and regulations with regards to zakah.Zakah is obligatory on both gold and silver. This obligation is revealed in more than one verse in the Quran. Among these verses is the saying of Allah in surah al-Tawbah, verses $34-35$ to the meaning:

"O you who have believed, indeed many of the scholars and the monks devour the wealth of people unjustly and avert [them] from the way of Allah. And those who hoard gold and silver and spend it not in the way of Allah - give them tidings of a painful punishment. The Day when it will be heated in the fire of Hell and seared therewith will be their foreheads, their flanks, and their backs, [it will be said], "This is what you hoarded for yourselves, so taste what you used to hoard".

There are several conditions that must be fulfilled before zakah is imposed on gold. These conditions are Islam, baligh (age of puberty), free from slavery, milk al-tam (full ownership), nisab (the lowest amount) and hawl (the completion of one year). As for the rate of zakah to be paid, the Muslim jurists are unanimous that it is 2.5\% (al-Bayjuri, 1994).

\section{The Knowledge of the Muslim in Terengganu on the Islamic Rules and Regulations Relating to Zakah} on Gold.

A set of questionnaire has been distributed to respondents in the state of Terengganu to evaluate how far is their knowledge on the Islamic rules and regulations related to the zakah on gold. The outcome of this questionnaire is as follow. 
INTERNATIONAL JOURNAL OF ACADEMIC RESEARCH IN BUSINESS AND SOCIAL SCIENCES

Vol. 8, No. 10, Oct. 2018, E-ISSN: 2222-6990 @ 2018 HRMARS

Schedule: Respondents' Min for Knowledge on Islamic Rules and Regulations Related to the Zakah on Gold

\begin{tabular}{|c|c|c|c|c|c|c|c|c|}
\hline \multirow[t]{3}{*}{ ITEM } & \multicolumn{8}{|c|}{ SCALE } \\
\hline & \multicolumn{4}{|c|}{ Very Disagree } & \multicolumn{4}{|r|}{ Very Agree } \\
\hline & 1 & 2 & 3 & 4 & 5 & 6 & 7 & 10 \\
\hline Zakah is one of the pillars of Islam & \multicolumn{8}{|c|}{9.3} \\
\hline $\begin{array}{r}\text { Zakah is categorised into two types i.e. } \\
\text { zakah fitrah and zakah on wealth }\end{array}$ & \multicolumn{8}{|c|}{9.7} \\
\hline $\begin{array}{r}\text { Zakah on gold is a type of zakah imposed } \\
\text { on wealth. }\end{array}$ & \multicolumn{8}{|c|}{7.1} \\
\hline $\begin{array}{c}\text { The owner of gold must pay zakah out of it } \\
\text { when they own it for at least one year. }\end{array}$ & \multicolumn{8}{|c|}{7.4} \\
\hline $\begin{array}{l}\text { The owner of gold must pay zakah out of it } \\
\text { when the amount of gold they own equal } \\
\text { or more than the nisab ( } 85 \text { gram) }\end{array}$ & \multicolumn{8}{|c|}{7.3} \\
\hline $\begin{array}{r}\text { The nisab for gold jewelleries is the same } \\
\text { as the nisab for gold bar }\end{array}$ & \multicolumn{8}{|c|}{7.8} \\
\hline $\begin{array}{l}\text { The rate of zakah imposed on gold is } 2.5 \% \\
\text { from the amount owned. }\end{array}$ & \multicolumn{8}{|c|}{7.7} \\
\hline $\begin{array}{l}\text { The total amount of gold that is kept by its } \\
\text { owner is the amount that must be } \\
\text { calculated for the purpose of zakah when it } \\
\text { reach the nisab. }\end{array}$ & \multicolumn{8}{|c|}{7.7} \\
\hline $\begin{array}{l}\text { The total amount of gold that is invested by } \\
\text { its owner is the amount that must be } \\
\text { calculated for the purpose of zakah when it } \\
\text { reach the nisab. }\end{array}$ & \multicolumn{8}{|c|}{6.5} \\
\hline $\begin{array}{l}\text { The total amount of gold that is pawned by } \\
\text { its owner is the amount that must be } \\
\text { calculated for the purpose of zakah when it } \\
\text { reach the nisab. }\end{array}$ & \multicolumn{8}{|c|}{7.9} \\
\hline $\begin{array}{l}\text { The zakah imposed on jewelleries that are } \\
\text { worn by a woman is on the amount } \\
\text { exceeds the normal customary amount } \\
\text { worn by woman in that area. }\end{array}$ & \multicolumn{8}{|c|}{7.1} \\
\hline $\begin{array}{r}\text { Gold that are used in forbidden way is } \\
\text { subjected to zakah when all conditions for } \\
\text { it are met }\end{array}$ & \multicolumn{8}{|c|}{8.4} \\
\hline $\begin{array}{r}\text { Gold jewelleries that are not worn are } \\
\text { subjected to zakah when all conditions for } \\
\text { it are met }\end{array}$ & \multicolumn{8}{|c|}{8.5} \\
\hline
\end{tabular}

All of the above questions can be concluded into several main questions that demonstrate the general knowledge of Muslims in Terengganu on the Islamic rules and regulations related to the obligation to pay zakah on gold. These main questions are as below: 
INTERNATIONAL JOURNAL OF ACADEMIC RESEARCH IN BUSINESS AND SOCIAL SCIENCES Vol. 8, No. 10, Oct. 2018, E-ISSN: 2222-6990 @ 2018 HRMARS

\begin{tabular}{|c|c|c|c|c|}
\hline \multicolumn{5}{|c|}{ Zakah is one of the Islamic pillars } \\
\hline & Yes & Uncertain & No & Total \\
\hline \multicolumn{5}{|c|}{ Sex } \\
\hline Male & 72 & 3 & 6 & 81 \\
\hline Female & 248 & 12 & 8 & 269 \\
\hline TOTAL & 320 & 15 & 14 & 350 \\
\hline \multicolumn{5}{|c|}{ District } \\
\hline Kuala Terengganu & 107 & 4 & 5 & 116 \\
\hline Marang & 30 & 3 & 0 & 33 \\
\hline Dungun & 56 & 1 & 1 & 58 \\
\hline Setiu & 34 & 2 & 1 & 37 \\
\hline Kemaman & 38 & 1 & 1 & 40 \\
\hline Besut & 34 & 3 & 4 & 41 \\
\hline Hulu Terengganu & 21 & 1 & 2 & 24 \\
\hline Total & 320 & 15 & 14 & 350 \\
\hline
\end{tabular}

In relation with the knowledge of the respondent about the position of zakah in Islam, it can be concluded that majority of the respondents understand it. Only 14 respondents (4\%) do not understand it while only 15 (representing 4.3\%) are uncertain about it. The majority i.e. 320 respondents (representing 91\%) understand the important position of zakah.

\begin{tabular}{|c|c|c|c|c|}
\hline \multicolumn{5}{|c|}{ The gold owner must pay the due zakah when he owns it more than one yea } \\
\hline & Yes & Uncertain & No & Total \\
\hline \multicolumn{5}{|c|}{ Sex } \\
\hline Male & 54 & 9 & 18 & 81 \\
\hline Female & 157 & 69 & 43 & 269 \\
\hline TOTAL & 211 & 78 & 61 & 350 \\
\hline \multicolumn{5}{|c|}{ District } \\
\hline Kuala Terengganu & 70 & 22 & 25 & 117 \\
\hline Marang & 15 & 14 & 4 & 33 \\
\hline Dungun & 42 & 8 & 8 & 58 \\
\hline Setiu & 20 & 13 & 4 & 37 \\
\hline Kemaman & 23 & 7 & 10 & 40 \\
\hline Besut & 22 & 12 & 7 & 41 \\
\hline Hulu Terengganu & 19 & 12 & 3 & 24 \\
\hline TOTAL & 211 & 78 & 61 & 350 \\
\hline
\end{tabular}

The respondents also demonstrate a good level of understanding towards the obligation to pay zakah on gold when it is owned for at least one year. Only 61 respondents (representing 17.4\%) do not 
INTERNATIONAL JOURNAL OF ACADEMIC RESEARCH IN BUSINESS AND SOCIAL SCIENCES Vol. 8, No. 10, Oct. 2018, E-ISSN: 2222-6990 ㄷ 2018 HRMARS

understand it while 78 respondents (representing 22.3\%) are not sure about it. The majority i.e. 211 respondents (representing 60.2\%) understand the obligation to pay zakah out of gold that is owned for at least one year.

\begin{tabular}{|c|c|c|c|c|}
\hline \multicolumn{5}{|c|}{$\begin{array}{l}\text { The Gold Owner Must Pay the Due Zakah When the Amount of Gold in His } \\
\text { Ownership Exceed the Nisab (85 gram). }\end{array}$} \\
\hline & Yes & Uncertain & No & Total \\
\hline \multicolumn{5}{|c|}{ Sex } \\
\hline Male & 51 & 11 & 19 & 81 \\
\hline Female & 177 & 62 & 30 & 269 \\
\hline TOTAL & 228 & 73 & 49 & 350 \\
\hline \multicolumn{5}{|c|}{ District } \\
\hline Kuala Terengganu & 72 & 21 & 24 & 117 \\
\hline Marang & 17 & 13 & 3 & 33 \\
\hline Dungun & 41 & 11 & 6 & 58 \\
\hline Setiu & 22 & 13 & 2 & 37 \\
\hline Kemaman & 26 & 5 & 9 & 40 \\
\hline Besut & 29 & 8 & 4 & 41 \\
\hline Hulu Terengganu & 21 & 2 & 1 & 24 \\
\hline TOTAL & 228 & 73 & 49 & 350 \\
\hline
\end{tabular}

The level of the respondents' understanding on the fulfilment of nisab to make the zakah payment as obligatory is also good. Majority of the respondents i.e. 228 respondents (representing 65.1\%) understand the condition of nisab in zakah obligation. Only 49 respondents (representing 14\%) do not understand it while a number of 73 respondents (representing $20.8 \%$ ) are uncertain about it.

\begin{tabular}{|c|c|c|c|c|}
\hline \multicolumn{5}{|c|}{$\begin{array}{l}\text { The zakah imposed on jewelleries that are worn by a woman is on the amount } \\
\text { exceeds the normal customary amount worn by woman in that area }\end{array}$} \\
\hline & Yes & Uncertain & No & Total \\
\hline \multicolumn{5}{|c|}{ Sex } \\
\hline Male & 59 & 16 & 6 & 81 \\
\hline Female & 186 & 62 & 21 & 269 \\
\hline TOTAL & 244 & 78 & 27 & 350 \\
\hline \multicolumn{5}{|c|}{ District } \\
\hline Kuala Terengganu & 80 & 21 & 16 & 117 \\
\hline Marang & 20 & 11 & 2 & 33 \\
\hline Dungun & 38 & 17 & 3 & 58 \\
\hline Setiu & 23 & 11 & 3 & 37 \\
\hline Kemaman & 34 & 6 & 0 & 40 \\
\hline Besut & 30 & 8 & 3 & 41 \\
\hline Hulu Terengganu & 20 & 4 & 0 & 24 \\
\hline TOTAL & 245 & 78 & 27 & 350 \\
\hline
\end{tabular}


INTERNATIONAL JOURNAL OF ACADEMIC RESEARCH IN BUSINESS AND SOCIAL SCIENCES Vol. 8, No. 10, Oct. 2018, E-ISSN: 2222-6990 ㄷ 2018 HRMARS

Respondents also demonstrate a good knowledge in relation to Islamic rules and regulations on the obligation to pay zakah when the ownership reaches at least one year. Only 61 respondents (representing $17.4 \%$ ) do not understand it while 78 respondents (representing $22.3 \%$ ) pare uncertain about it. The majority i.e. 211 respondents (representing 60.2\%) know about that obligation.

\begin{tabular}{|c|c|c|c|c|}
\hline \multicolumn{5}{|c|}{$\begin{array}{l}\text { Gold jewelleries that are not worn are subjected to zakah when all conditions } \\
\text { for it are met }\end{array}$} \\
\hline & Yes & Uncertain & No & Total \\
\hline \multicolumn{5}{|c|}{ Sex } \\
\hline Male & 67 & 8 & 6 & 81 \\
\hline Female & 216 & 41 & 12 & 269 \\
\hline TOTAL & 283 & 49 & 18 & 350 \\
\hline \multicolumn{5}{|c|}{ District } \\
\hline Kuala Terengganu & 98 & 13 & 6 & 117 \\
\hline Marang & 24 & 8 & 1 & 33 \\
\hline Dungun & 50 & 4 & 4 & 58 \\
\hline Setiu & 24 & 9 & 4 & 37 \\
\hline Kemaman & 35 & 4 & 1 & 40 \\
\hline Besut & 31 & 8 & 2 & 41 \\
\hline Hulu Terengganu & 21 & 3 & 0 & 24 \\
\hline TOTAL & 283 & 49 & 18 & 350 \\
\hline
\end{tabular}

In relation to Islamic rules and regulations related to zakah on gold jewelleries that are not worn, majority of the respondents have also shown a good level of knowledge. A number of 283 respondents (representing 81\%) acknowledge the obligation to pay zakah out on jewelleries that are not worn when all other conditions for it are met. Only 18 respondents (representing 5.1\%) do not know about it and 49 respondents (representing 14\%) are not sure about it.

\section{CONCLUSION}

The level of knowledge among Muslims in Terengganu on the Islamic rules and regulation related to zakah on gold is good. Majority of the respondents have given correct answers for all relevant questions. In terms of the respondents' knowledge on the obligation of zakah on gold, it can be concluded that majority of them have good knowledge on it. A number of 320 respondents (representing 91\%) answer the related question correctly. The respondents also possess a good knowledge on the obligation to pay zakah in case where ownership reaches at least one year. Majority of the respondents with numbers amounting to 211 respondents (representing 60.2\%) understand it. The level of respondents' knowledge on the condition of nisab is also good. The majority of 228 respondents (representing 65.1\%) understand this condition. Majority of the respondents also knows that gold jewelleries that are not worn are subjected to zakah when all other conditions are met. A number of 283 respondents (representing $81 \%$ ) are of this opinion which is no doubt in line with the related Islamic rules and regulation. 
However, this does not in any way means that effort to educate Muslim society on rules and regulations related to the usage of gold is not necessary. This study reveals that there is a proportional number of Muslims who have poor grasp on this pertinent aspect of zakah. Although they are not many but the duty to improve their understanding cannot be neglected. Hence, adequate steps to enhance the understanding and knowledge among Muslims on the using of gold ought to be taken by multidisciplinary approach and close collaborations among respective institutions.

\section{ACKNOWLEDGEMENT}

This article is part of a research fund sponsored and managed by the Center for Research and Innovation (RMIC), Sultan Zainal Abidin University (UniSZA), Gong Badak Campus 21300 Kuala Nerus, Terengganu, Malaysia.

\section{REFERENCES}

Ali, E.M.T.E., Mohamad, M. \& Taha, A.T. (2015). Panduan Syarak tentang emas. Kuala Lumpur: Dewan Bahasa dan Pustaka.

Rushd, I. (n.d.). Vol. 1, Bidayah al-mujtahid wa nihayah al-muqtaahîid. Jaddah: Al-Haramayn li alTiba'ah wa al-Nashr.

Al-Bayjuri, I. (1994). Vol. 1, Hashiyah al-Shaikh Ibrahim al-Bayjuri. Bayrut, Lubnan: Dar al-Kutub al'Ilmiyyah.

Al-Qaradawi, Y. (1986). Vol. 1 \& 2, Fiqh al-zakah. Bayrut: Muassasah al-Risalah. Al-Sharbini, K. (1978). Vol. 1 \& 4, Mughni al-Muhtaj. Bayrut: Dar al-Fikr.

Al-Zuhayli, W. (1989). Vol. 2, Al-Fiqh al-Islami wa adillatuhu. Dimashq: Dar al-Fikr. 